\title{
Partial Characterization of Digestive Proteases in the Common Snook Centropomus undecimalis
}

\author{
B. Bartolo Concha-Frias ${ }^{1}$, Carlos A. Alvarez-González ${ }^{1}$, Martha G. Gaxiola-Cortes ${ }^{2}$, Alfonso E. Silva-Arancibia ${ }^{3}$, \\ Pedro H. Toledo-Agüero ${ }^{3}$, Rafael Martínez-García ${ }^{1}$, Susana Camarillo-Coop ${ }^{1}$, Luis D. Jimenez-Martinez ${ }^{1}$ \\ \& Joe L. Arias-Moscoso ${ }^{4}$ \\ ${ }^{1}$ Laboratorio de Acuacultura Tropical, DACBIOL-Universidad Juárez Autónoma de Tabasco. Carretera \\ Villahermosa Cárdenas Km 0.5, 86139, Villahermosa, Tabasco, Mexico \\ ${ }^{2}$ Unidad Multidisciplinaria de Docencia e Investigación, Facultad de Ciencias, UNAM, Puerto de Abrigo s/n, Sisal, \\ Yucatán, Mexico \\ ${ }^{3}$ Universidad Católica de Chile, Campus Guayacan Larrondo 1281, Coquimbo, Chile \\ ${ }^{4}$ DIPA, Universidad de Sonora, Blvd. L. Encinas y Rosales, Hermosillo, Sonora, 83,000, Mexico \\ Correspondence: Carlos A. Alvarez-González, Laboratorio de Acuacultura Tropical, DACBIOL-Universidad \\ Juárez Autónoma de Tabasco. Carretera Villahermosa Cárdenas Km 0.5, 86139, Villahermosa, Tabasco, Mexico. \\ E-mail: alvarez_alfonso@hotmail.com
}

Received: July 20, 2016

Accepted: August 2, 2016

Online Published: August 5, 2016

doi:10.5539/ijb.v8n4p1

URL: http://dx.doi.org/10.5539/ijb.v8n4p1

\begin{abstract}
Common snook (Centropomus undecimalis) is a marine species with high aquaculture potential; although its digestive physiology is still unknown and knowledge of that could allow the development of a balanced feed for commercial culture of this fish. The objective of this study was to partially characterize the digestive proteases in C. undecimalis using electrophoretic and biochemical techniques. A total of 50 wild snook juveniles were used to determine the optimal values of $\mathrm{pH}$ stability and temperature as well as the effect of inhibitors on digestive, gastric and intestinal proteases. The optimal $\mathrm{pH}$ for gastric proteases was obtained to be 2 with stability obtained between 2 and 8; the optimal temperature was detected at $75^{\circ} \mathrm{C}$ for in vitro test, and the thermal stability was between 25 and $45^{\circ} \mathrm{C}$. Intestinal proteases showed two peaks of activity at a $\mathrm{pH}$ of 7 and 11; meanwhile, the greatest stability was found between a $\mathrm{pH}$ of 4 and 10 ; the optimal temperature was at $65^{\circ} \mathrm{C}$, and the greatest stability was detected between 35 and $45^{\circ} \mathrm{C}$. Up to $86 \%$ of the gastric protease activity was inhibited by pepstatin A; meanwhile, the intestinal proteases TPCK, TLCK, 1-10 Phenanthroline, SBT1, EDTA, PMSF and ovalbumin reduced the activity by $17 \%, 68 \%, 85 \%, 41 \%, 40.5 \%, 60 \%$ and $59 \%$, respectively.
\end{abstract}

Keywords: common snook, digestion, proteases, nutrition

\section{Introduction}

The nutrient requirement in a fish species varies depending on several factors and it is determined by the quantity and quality of macronutrients (proteins, lipids and carbohydrates) and micronutrients (vitamins and minerals) (Fenerci, \& Sener, 2005). Digestion in fish starts in the digestive tract, where several proteases act and are responsible for protein hydrolysis (Tufan, Suzer, Taşbozan, \& Tabakoğlu, 2008); however, the activity expressed in International Units (IU mg protein ${ }^{-1}$ ) depends on the feeding habits and type of food, among other factors (Kuz'mina, 2008). Additionally, the protease activity could be affected by the quality of the ingredients composing the formula (Lazzari et al. 2010; Costa et al. 2011). Considering the above, the secretion of digestive enzymes depends on the physicochemical characteristics of the internal environmental, the quality and quantity of nutrients, and the presence of inhibitors in the feed (Lazo, Mendoza, Holt, Aguilera, \& Arnold, 2007; Murashita et al. 2015). In this sense, the studies on protease characterization allow us to understand the capacity of fish to hydrolyze and metabolize proteins, which are necessary for adequate growth and development (Ma et al. 2005). For several years many studies have been conducted to characterize digestive proteases such as in common dentex (Dentex dentex), blue discus (Symphysodon aequifasciata), burbot (Lota lota) and common carp (Cyprinus carpio) (Alarcón, Díaz, Moyano, \& Abellan, 1998; Chong, Natalia, \& Hashim, 2002a; Izvekova, Solovyev, Kashinskaya, \& Izvekov, 2013; Farhoudi, Abedian, Nazari, \& Makhdoomi, 2013). In Mexico, the culture of 
marine fish is based on a few species such as spotted rose snapper (Lutjanus guttatus) (Ibarra-Castro, \& Alvarez-Lajonchère, 2011), totoaba (Totoaba macdonaldi) (Galaviz, et al. 2015) and red drum (Sciaenops ocellatus) (Gatlin III, 2002). In the State of Tabasco one of the most important commercial species is the common snook (Centropomus undecimalis), which is considered a euryhaline species with many adequate biological characteristics for its culture (Alvarez-Lajonchère, \& Taylor, 2003); nevertheless, digestive physiology related to the changes of the digestive enzyme during initial ontogeny has been briefly studied (Jiménez-Martínez et al. 2012). Hence, the objective of this study was to characterize digestive proteases in C. undecimalis juveniles.

\section{Materials and METHODS}

\subsection{Handling of Fish and Sampling}

For the enzymatic characterization and in vitro digestibility bioassays, common snook juveniles were obtained from the wild from the Arroyo Verde community located in Comalcalco municipality borders, Tabasco, México. The fish were captured with conical nets, 15 meters in length and 3 meters deep. Once captured, the fish (50 juveniles, $13.98 \pm 5.54 \mathrm{~g}$ average) were transported in aerated containers to the Laboratorio de Acuicultura Tropical at the División Académica de Ciencias Biológicas at the Universidad Juárez Autónoma de Tabasco, México, and fed with Nile Tilapia (Oreochromis niloticus) fry in plastic tanks of $2000 \mathrm{~L}$ during a period of 20 days until processing.

\subsection{Multienzymatic Extracts Preparation}

After the captivity adaptation period, the fish were starved for a 24-hour period and then exposed to an overdose of tricaine methanesulfonate (MS-222, $0.30 \mathrm{mg} \mathrm{L}^{-1}$ ). The digestive apparatus was extracted from each fish, and the stomach and gut were separated and stored at $4^{\circ} \mathrm{C}$ to avoid enzymatic denaturation. Gut samples were homogenized in a buffer of $50 \mathrm{mmol} \mathrm{L}-1$ Tris- $\mathrm{HCl}$ and $\mathrm{CaCl}_{2} 20 \mathrm{mmol} \mathrm{L}-1$ at a $\mathrm{pH}$ of $7.5\left(35 \mathrm{mg} \mathrm{mL}^{-1}\right)$. The stomachs were homogenized in a buffer of $100 \mathrm{mmol} \mathrm{L}^{-1}$ Glycine- $\mathrm{HCl}$ at a $\mathrm{pH}$ of 2.0. The samples were centrifuged at $16000 \mathrm{~g}$ for $30 \mathrm{~min}$ at $4{ }^{\circ} \mathrm{C}$ to obtain the supernatant, placed in Eppendorf tubes and stored at $-20{ }^{\circ} \mathrm{C}$ for further analysis.

\subsection{Optimal $\mathrm{pH}$ and Temperature}

Optimal $\mathrm{pH}$ was measured using the method described by Walter (1984), for the optimum $\mathrm{pH}$ for alkaline proteases (gut extracts) casein $\left(1 \mathrm{~g} \mathrm{~kg}^{-1}\right)$ was used as the substrate, whereas for acid proteases (stomach extracts) the Anson (1938) technique was applied using hemoglobin $\left(1 \mathrm{~g} \mathrm{~kg}^{-1}\right)$ as substrate. For $\mathrm{pH}$ adjustment the original buffers $\left(50 \mathrm{mmol} \mathrm{L}^{-1}\right.$ Tris- $\mathrm{HCl}$ and $20 \mathrm{mmol}^{-1} \mathrm{CaCl}_{2}$ with a pH of 7.5 , and $100 \mathrm{mmol} \mathrm{L}^{-1}$ Glycine-HCl with a pH of 2.0) were substituted with the universal solution (Stauffer, 1989) to be adjusted to different pH levels for measuring the $\mathrm{pH}$ activities from 2 to 12 . The optimal temperature for the stomach and gut proteases was measured with the techniques of Walter (1984), and Anson (1938), respectively, and modified at the temperatures of $25,35,45,55$ and $65{ }^{\circ} \mathrm{C}$. The incubation time in both cases were carried out for 5 minutes for acid proteases and 20 minutes for alkaline, and all assays were performed in triplicate.

\subsection{Temperature and $p H$ Stability}

For $\mathrm{pH}$ stability, multi-enzymatic extracts were pre-incubated to the different $\mathrm{pH}$ levels for $0,30,60$ and $90 \mathrm{~min}$. The incubation was performed at room temperature. The optimal temperature for acidity and alkalinity was determined by modifying the incubation temperature within a $25-65^{\circ} \mathrm{C}$ range with $10{ }^{\circ} \mathrm{C}$ intervals according to Anson (1938), and Walter (1984), respectively. To determine protease stability in relation to temperature changes, multi-enzymatic extracts were pre-incubated to the different temperatures previously mentioned for 0 , 30, 60 and $90 \mathrm{~min}$. For $\mathrm{pH}$ and temperature stability, the time of $0 \mathrm{~min}$ (no pre-incubation) was used as a control to determine the residual activity expressed as a percentage. All assays were performed in triplicate.

\subsection{Effect of Inhibitors}

The protease inhibition activity was determined as follows. For acidic proteases, pepstatin A inhibitor was used, and residual activity was determined with the method described by Anson (1938). In alkaline proteases, specific inhibitors were used as described by García-Carreño, Dimes, \& Haard (1993). For residual activity on alkaline proteases, the technique described by Kunitz (1947) and modified by Walter (1984) was used. In both trials, a control with no inhibitor was used, and the residual activity was expressed as a percentage. All trials were conducted in triplicate. The analysis of the effect of inhibitors on the alkaline proteases was accompanied by SDS-PAGE electrophoresis in denaturalization processes using sodium dodecyl sulfate (SDS)-polyacrylamide gel. Four percent stacking gel and $10 \mathrm{~g} \mathrm{~kg}^{-1}$ running gel were used according to Laemmli (1970), with the protocol of Davis (1964) as modified by García-Carreño, Albuquerque-Cavalcanti, Navarrete del Toro, \& Zaniboni-Filho (2002). Seven inhibitors were used as described by García-Carreño, Albuquerque-Cavalcanti, Navarrete del Toro, 
\& Zaniboni-Filho (1993), and they were pre-incubated in a 1:1 ratio (enzyme/inhibitor) for $1 \mathrm{~h}$. A Bio Basic Inc. (Markham, Ontario, Canada) BM523 molecular weight marker was used along with Quantity One 1-D Analysis Software from Bio-Rad (Hercules, CA, USA) to calculate each molecular weight in each band.

To measure the effect of inhibitors on acidic protease activity, pepstatin $\mathrm{A}\left(1 \mathrm{mmol} \mathrm{L} \mathrm{L}^{-1}\right)$ was used, whereas for alkaline proteases the following specific inhibitors described by García-Carreño, Dimes, \& Haard (1993) were used: phenylmethylsulfonyl fluoride (PMSF, $100 \mathrm{mmol} \mathrm{L}^{-1}$ ), soy trypsin inhibitor (SBT1, $250 \mathrm{mmol} \mathrm{L}^{-1}$ ), tosyl-phenylalanine chloromethyl ketone (TPCK, $10 \mathrm{mmol} \mathrm{L}^{-1}$ ), tosyl-lysyl chloromethyl ketone (TLCK, 10 mmol L-1), tetra acetate ethylene diamine (EDTA, $\left.10 \mathrm{mmol} \mathrm{L}^{-1}\right)$, ovalbumin $\left(250 \mathrm{mmol} \mathrm{L}^{-1}\right)$ and phenanthroline $\left(10 \mathrm{mmol} \mathrm{L}^{-1}\right)$. The multi-enzymatic extracts were pre-incubated for an hour in a ratio of 1:1 with the different inhibitors, and the residual activity was measured in relation to an extract without pre-incubation and with no inhibitor. All assays were performed in triplicate.

\subsection{Electrophoretic Analysis}

Polyacrylamide electrophoresis was performed under denatured conditions (using sodium sulfate dodecyl) discontinuously for alkaline proteases following the protocol of Laemmli (1970), using a storer gel at $4 \%$ and slipping at $10 \%$. The electrophoresis was performed in Mini PROTEAN III buckets (Bio-Rad) with two plates of vertical gels of $8 \times 10 \times 0.075 \mathrm{~cm}$ with a capacity of 20 . The samples were prepared for the alkaline protease zymograms according to the method described by García-Carreño, Dimes, and Haard (1993) by running at $100 \mathrm{~V}$ at $5{ }^{\circ} \mathrm{C}$ for $60 \mathrm{~min}$. The gels were rinsed with distilled water and incubated for $30 \mathrm{~min}$ at $5{ }^{\circ} \mathrm{C}$ in a casein solution of Hammerstein at $5 \%$ with a $\mathrm{pH}$ of 9 . The inhibition analysis of the gut extracts was conducted with the same inhibitors mentioned earlier with preincubation for 1 hour. The gels were incubated for $90 \mathrm{~min}$ in the same solution at $37{ }^{\circ} \mathrm{C}$ with no agitation. Finally, the gels were fixed with a TCA solution at $12 \%$ and stained with $0.1 \%$ Coomassie R-250 brilliant blue, methanol, acetic acid and water (50:20:50) for $1 \mathrm{~h}$ and unstained with methanol-acetic acid-water (35:10:55). The clear zones indicated the presence of alkaline proteases after a period of 24 clearing hours; finally, the bands that appeared were compared with those of a control with no inhibitor.

For the analysis of acidic proteases continuous polyacrylamide electrophoresis was conducted under native conditions (10\%). The electrophoresis conditions used were described by Walter (1984) and performed at $100 \mathrm{~V}$ and $64 \mathrm{~mA}$ by gel. To reveal the isoforms, the Díaz-López, Moyano-lópez, Alarcón-López, García-Carreño, \& Navarrete-del Toro (1998) procedure was followed using a porcine pepsin solution $\left(1 \mathrm{mg} \mathrm{mL}^{-1}\right.$, Sigma, 2,500-3,500 $\mathrm{U} \mathrm{mg}$ of protein ${ }^{-1}$ ) as a reference enzyme at a concentration of $30 \mu \mathrm{g}$ of protein by well. After the electrophoresis, the gels were rinsed with $\mathrm{HCl} 0.1 \mathrm{mmol} \mathrm{L}^{-1}$ at a $\mathrm{pH}$ of 2.0 for acidic protease activation. After 15 minutes, the gels were incubated for 30 minutes at $4^{\circ} \mathrm{C}$ in a hemoglobin solution $0.25 \%$ in a buffer solution of glycine- $\mathrm{HCl} 100 \mathrm{mmol} \mathrm{L}^{-1} \mathrm{pH} \mathrm{2.0}$; after 90 minutes the same solution was used for a final incubation at $37^{\circ} \mathrm{C}$. To evaluate the inhibition of the stomach extracts of $C$. undecimalis, pepstatin A was used in a $1: 1$ (enzyme/inhibitor) proportion; preincubation with the inhibitor was performed for 1 hour, and porcine pepsin used as the reference enzyme. Finally, the gels were rinsed with distilled water and fixed with a solution of TCA at $12 \%$ for 15 minutes according to the aforementioned procedures with alkaline proteases.

\subsection{Relative Migration Distance and Molecular Weight Calculation}

A low-weight molecular weight marker was used (LRMWM) and applied for each SDS-PAGE with $5 \mu$ added for the well. The LRMWM contained the following protein markers: phosphorylase $\mathrm{b}(97 \mathrm{kDa})$, serum bovine albumin $(66 \mathrm{kDa})$, egg albumin $(45 \mathrm{kDa})$, carbonic anhydrase $(29 \mathrm{kDa})$, trypsinogen $(24 \mathrm{kDa})$ and tryptic soy inhibitor $(20 \mathrm{kDa})$. The relative electromobility (Rf) was calculated for all of the zymograms (Igbokwe \& Downe, 1978), and the molecular weight (MW) of each band with alkaline protease activity was calculated as the lineal adjustment between $\mathrm{Rf}$ and the decimal logarithm of the molecular weights of the proteins used as markers using the software Quality One V 4.6.5 (Hercules, CA).

\section{Results}

The optimal $\mathrm{pH}$ for gastric proteases was obtained at a $\mathrm{pH}$ of 2 . It decreased drastically at a $\mathrm{pH}$ of 5 when the environment turned more alkaline (Figure 1a). The intestinal protolithic enzymes showed two peaks, the highest at a $\mathrm{pH}$ of 7, and its activity was reduced at the $\mathrm{pH}$ range from 8 to 10 . The second peak of activity occurred at a $\mathrm{pH}$ of 11, decreasing at a $\mathrm{pH}$ of 12 (Figure 1b). The optimal temperature of the acidic proteases was shown at 75 ${ }^{\circ} \mathrm{C}$, decreasing at $85^{\circ} \mathrm{C}$ (Figure 1c); meanwhile, the optimal activity of the alkaline proteases was registered at 65 ${ }^{\circ} \mathrm{C}$; they showed high activity from $45^{\circ} \mathrm{C}$ until a drastic fall at $75^{\circ} \mathrm{C}$ (Figure 1d). The greater stability in acidic proteases was at a $\mathrm{pH}$ of 2 and 8 , and it decreased with increasing $\mathrm{pH}$ (Figure 2a); meanwhile, the alkaline proteases could be more stable between the $\mathrm{pH}$ values of 4 and 10 at periods of preincubation of greater than 120 minute (Figure 2b). Acidic protease activity increased for 25,35 and $45{ }^{\circ} \mathrm{C}$ at 90 minutes of incubation (Figure 
2c). Meanwhile, in alkaline proteases greater activity was exhibited at $35-45^{\circ} \mathrm{C}$ after 90 minutes of incubation (Figure 2d).
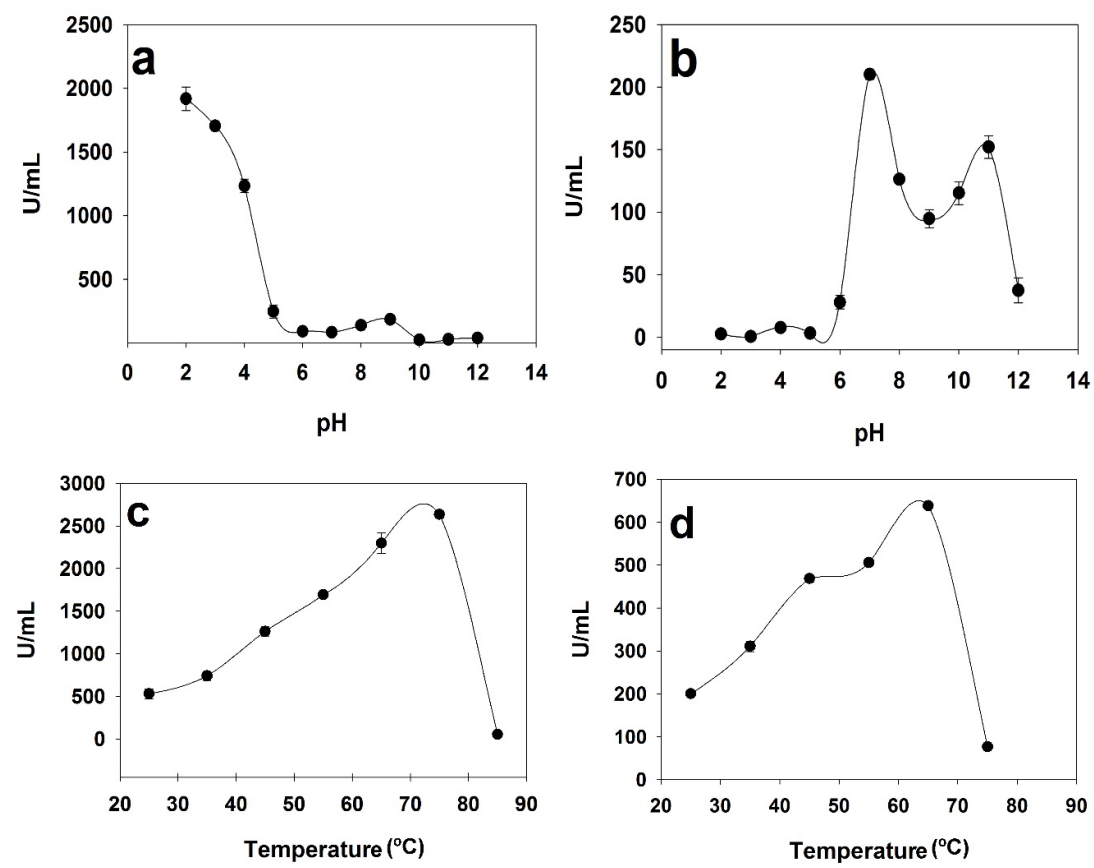

Figure 1. Optimum $\mathrm{pH}$ and temperature on digestive proteases of Centropomus undecimalis juvenile: (a) optimum $\mathrm{pH}$ acid proteases, (b) optimum $\mathrm{pH}$ alkaline proteases, (c) optimum temperature acid proteases, (d) optimum temperature alkaline proteases
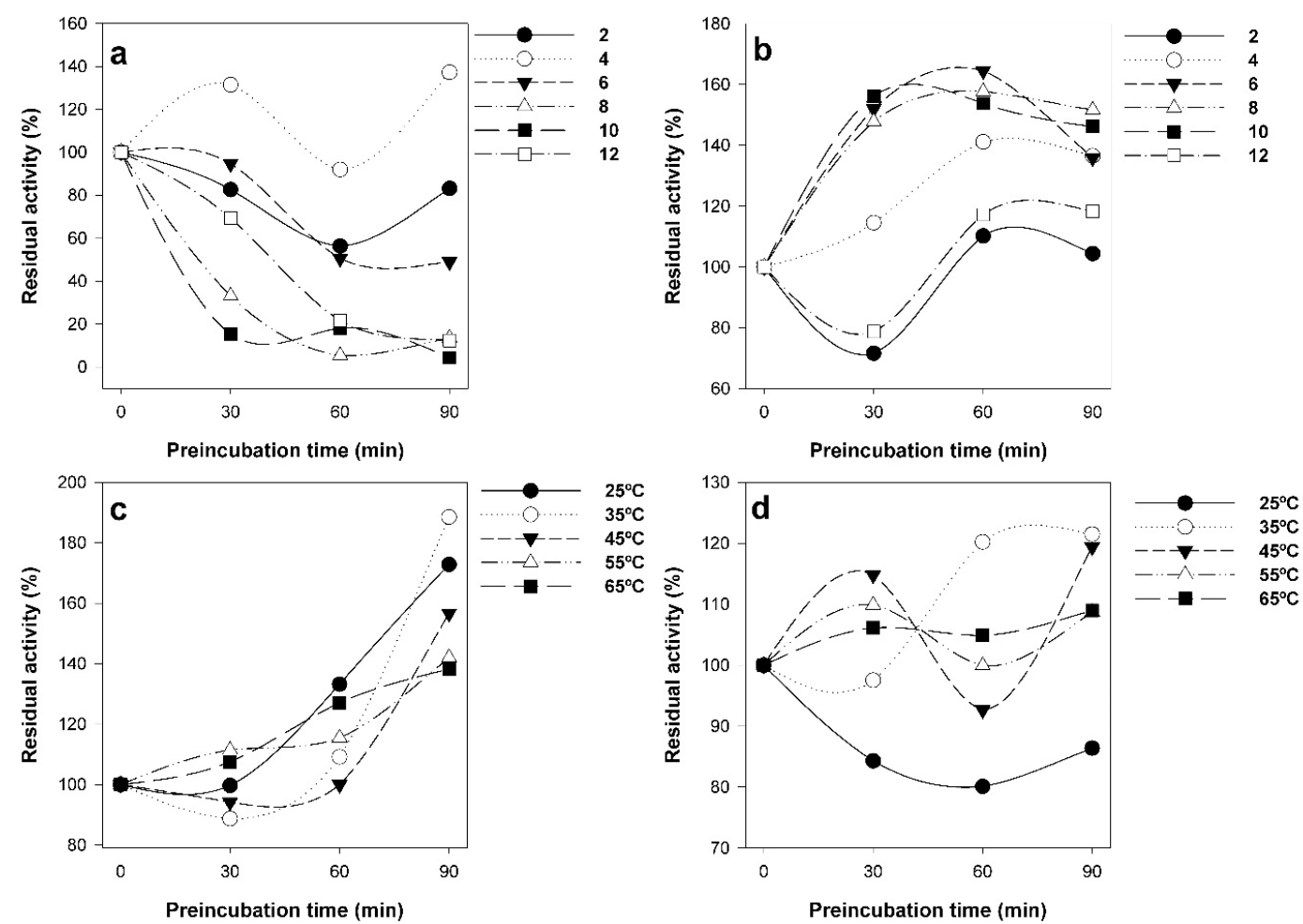

Figure 2. Stability of $\mathrm{pH}$ and temperature on digestive proteases of Centropomus undecimalis juvenile: (a) $\mathrm{pH}$ stability of acid proteases, (b) $\mathrm{pH}$ stability of alkaline proteases, (c) temperature stability of acid proteases, (b) temperature stability of alkaline proteases 

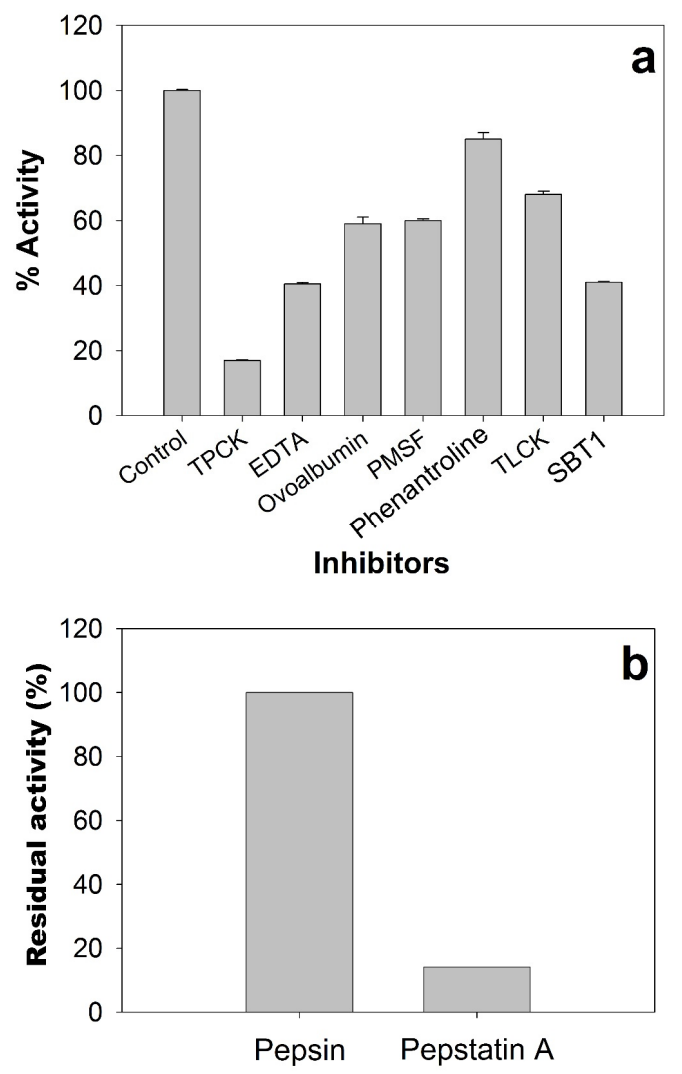

Figure 3. Effect on digestive protease activity reduction in multi-enzymatic extracts of Centropomus undecimalis juveniles by different inhibitors. (a) Alkaline proteases with no inhibitor (Control), tosylphenylanyl-chloromethyl ketone (TPCK), phenanthroline (Phen), ethyl-diamine tetra-acetic acid (EDTA), tosyl-lysyl-chloromethyl ketone (TLCK), ovalbumin (OVO), soybean trypsin inhibitor (SBT1), phenyl methyl sulphonyl fluoride (PMSF). (b) Acid proteases with no inhibitor (Pepsin), pepstatin A

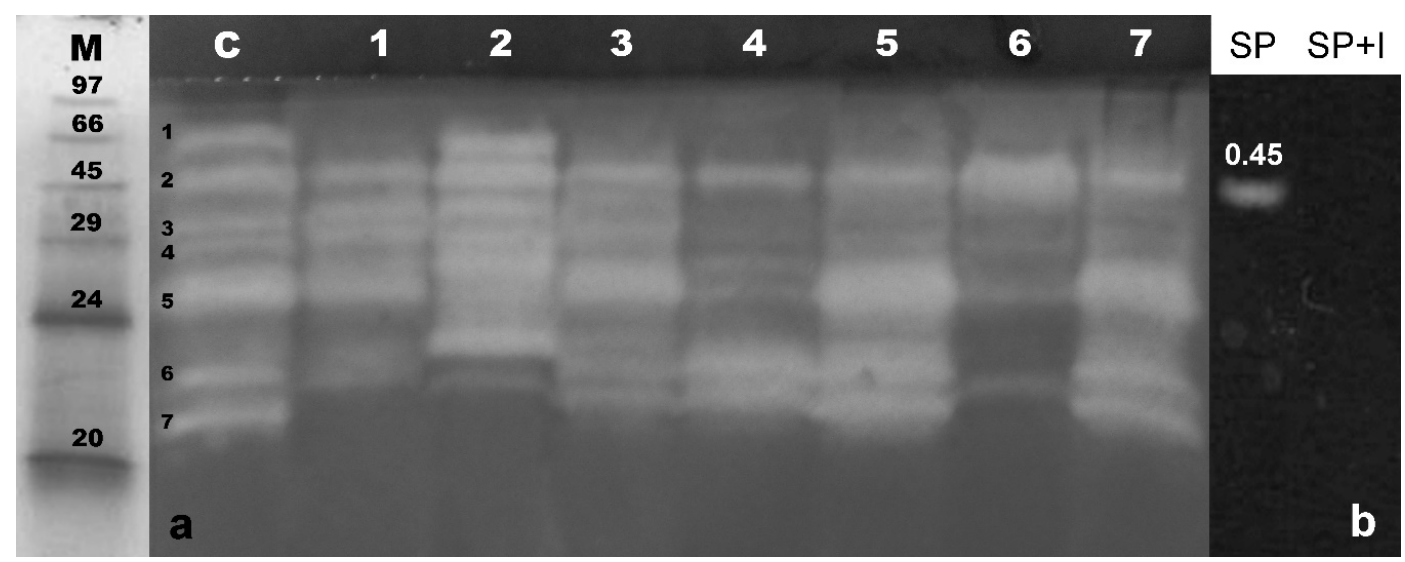

Figure 4. (a) SDS-PAGE electrophoresis analysis of alkaline digestive proteases of Centropomus undecimalis juveniles: M (LRMWM): phosphorylase b $(97 \mathrm{kDa})$, serum bovine albumin $(66 \mathrm{kDa})$, turkey egg albumin (45 $\mathrm{kDa})$, carbonic anhydrase $(29 \mathrm{kDa})$, trypsinogen $(24 \mathrm{kDa})$ and trypsin soybean inhibitor $(20 \mathrm{kDa})$; the control (band 1: 65.2, band 2: 45.6, band 3: 30.1, band 4:28.7, band 5: 25.2, band 6: 22.6 and band 7:21.3 kDa); inhibitors:

Line 1: Phenyl methyl sulphonyl fluoride (PMSF); Line 2: Soybean trypsin inhibitor (SBT1); Line 3:

Tosyl-phenylanyl-chloromethyl ketone (TPCK); Line 4: Tosyil-lysyl-chloromethyl ketone (TLCK); Line 5:

Phenanthroline (Phen); Line 6: Ovalbumin (OVO); and Line 7: Ethyl-diamine tetra-acetic acid (EDTA). (b) effect of pepstatin A on common snook pepsin. SP: Snook pepsin, SP+I: snook pepsin + inhibitor 
For the inhibition test, the enzymatic extracts of $C$. undecimalis juveniles showed that tosyl phenylalanyl chloromethyl ketone (TPCK) reduced alkaline protease activity by $17 \%$, while tosyl lysyl chloromethyl ketone (TLCK) inhibited it by $68 \%$. The 1-10 phenanthroline showed a greater inhibition percentage with $85 \%$, soy trypsin inhibitor (SBT1) reduced the activity by $41 \%$, EDTA (ethylenediaminetetraacetic acid) showed $40.5 \%$ activity reduction, PMSF (phenyl-methylsulfonyl fluoride) reduced the proteolytic activity by $60 \%$ and the ovalbumin inhibited the intestinal proteases activity by $59 \%$ (Figure 3a). Eighty-six percent of the acid proteases were affected when preincubated with pepstatin A compared with the control without an inhibitor (Figure 3b).

The data obtained by the SDS-PAGE technique showed three active bands, indicating the presence of three alkaline digestive protease groups which where inhibited partially by the inhibitors PMSF, TLCK, TPCK, Ovalbumin, SBT1, EDTA and 1-10 phenanthroline. The inhibitors TPCK, 1-10 phenanthroline, EDTA and PMSF inactivated the expression of the three proteolytic bands in common snook, whereas TLCK and ovalbumin only inhibited one band and SBT1 inhibited two active bands of alkaline proteases (Figure 4a). The inhibition of acid proteases showed only one active band, which was inhibited completely by pepstatin A. In this assay porcine pepsin was used as the control enzyme, and it was inhibited by the same inhibitor (Figure 4b).

\section{Discussion}

In common snook, the pepsin activity was greater $\left(25 \mathrm{U} \mathrm{mL}^{-1}\right)$ than the activity exhibited by the alkaline proteases (17 units $\mathrm{ml}^{-1}$ ), revealing that the digestion of protein is performed mostly in the stomach followed by the intestines. Similar data have been reported for Scleropages formosus, Solea senegalensis and Glyptosternum maculatum (Natalia, Hashim, Ali, \& Chong 2004; Saénz et al. 2005; Xiong, Xie, Zhang, \& Liu, 2011). Pepsin is the main acid protease in fish stomach, and the first protolithic enzyme requires it for breaking large polypeptide chains (Tengjaroenkul, Smith, Caceci, \& Smith, 2000; Zhao, Budge, Ghaly, Brooks, \& Dave, 2011); it showed an optimal pH of 2, reported earlier for S. senegalensis, Scophthalmus maximus L. and C. carpio L. (Saénz et al. 2005; Wang, Wang, Wang, Xue, \& Sun, 2006; Al-Saraji, \& Nasir, 2013). It was stable for different pH values with a minor decline at alkaline $\mathrm{pH}$ levels showed an increase in activity after 60 minutes of incubation and destabilized at a $\mathrm{pH}$ of 10. Similar results were reported by Wang, Wang, Wang, Xue, and Sun (2006), in S. maximus, which showed instability at a $\mathrm{pH}$ of 8 . This enzyme can hydrolyze the protein until the foregut where the $\mathrm{pH}$ increases and alkaline proteases start their activity (Alarcón, Díaz, Moyano, \& Abellan, 1998; Álvarez-González, 2003; Sankar, Varadarajan, Bhanu, Joy, \& Philip, 2014). Castillo-Yañez, Pacheco-Aguilar, García-Carreño, \& Navarrete-Del Toro (2004), indicated that in warm water species, gastric proteases are stable at neutral $\mathrm{pH}$.

Alkaline proteases showed two peaks at a $\mathrm{pH}$ of 7 and 11. Similar results have been reported for $S$. aequifasciata, T. thynnus, P. maculatofasciatus and B. splendens (Chong, Hashim, \& Bin Ali, 2002b; Essed, Fernández, Alarcón, \& Moyano, 2002; Álvarez-González, 2003), suggesting that the peak at a pH of 7 could be due to the trypsin because the optimal pH ranges from 7 to 9 (Das, \& Tripathi, 1991; Castillo-Yáñez, Pacheco-Aguilar, García-Carreño, \& Navarrete-Del Toro, 2005) while chymotrypsin works at a pH between 9 and 11. Our results are similar to those reported by Klahan, Areechon, Yoonpundh, \& Engkagul (2009), for O. niloticus. Alkaline proteases in snook are stable at $\mathrm{pH}$ values from 4 to 10 during the first 120 minutes of incubation, decreasing their activity at 180 minutes, destabilizing in the first 60 minutes at extreme $\mathrm{pH}$, and showing greater activity at a pH of 8. This is similar to that reported by Álvarez-González (2003) in P. maculatofasciatus.

Considering the above-mentioned, Thongprajukaew, Kovitvadhi, Engkagul, \& Rungruangsak-Torrissen (2010). and Xiong et al. (2011) reported an optimal temperature for acid proteases at $50-60^{\circ} \mathrm{C}$ in $B$. splendens and $G$. maculatum with denaturalizing after $60^{\circ} \mathrm{C}$. Although, pepsin in C. undecimalis showed an optimal temperature at $75^{\circ} \mathrm{C}$. In this sense, Korostelev, Nevalenny, and Levchenko (2005), reported that fish digestive enzymes could be adapted to the operating conditions to ensure optimal digestive functions. The tolerance to high temperatures from snook pepsin can be a biological adaptation of the enzyme because this fish inhabits warm waters ranging from 15 to $35^{\circ} \mathrm{C}$ (Tucker Jr, 2003). Acid proteases were stable at temperatures from 25 to $45^{\circ} \mathrm{C}$ with greater activity at 90 minutes of exposure and decreasing after 60 minutes at $65^{\circ} \mathrm{C}$, indicating a loss in activity after 90 minutes of exposure, which was similar to the study of Castillo-Yañez, Pacheco-Aguilar, Garcia-Carreño, \& Navarrete-Del Toro (2004), whom reported for Monterrey sardine Sardinops sagax caerulea an inverse relation where if temperature and incubation time increases, the gastric protease activity decrease.

Alkaline optimal temperatures for studied in fish ranges from 30 to $60^{\circ} \mathrm{C}$ (Alarcón, Díaz, Moyano, \& Abellan, 1998). The alkaline proteases in snook showed maximum proteolytic activity at $65^{\circ} \mathrm{C}$, similar to what was reported for $B$. orbignyanus and T. thynnus (Essed, Fernández, Alarcón, \& Moyano, 2002; García-Carreño, Albuquerque-Cavalcanti, Navarrete del Toro, \& Zaniboni-Filho, 2002), and temperature stability from 45 to $65^{\circ} \mathrm{C}$, showing maximum activities at temperatures of 35 and $45^{\circ} \mathrm{C}$ at 90 minutes of incubation. García-Carreño, Albuquerque-Cavalcanti, Navarrete del 
Toro, \& Zaniboni-Filho (2002), reported temperature stability at $50^{\circ} \mathrm{C}$ for $B$. orbignyanus, whereas Álvarez-González (2003) found stability at 45 and $55^{\circ} \mathrm{C}$ at 90 minutes of preincubation for $P$. maculatofasciatus. In this study the acid proteases showed more stability than alkaline proteases, although Essed, Fernández, Alarcón, \& Moyano (2002), found greater stability for alkaline proteases in T. thynnus than acid proteases.

Acid protease activity was reduced by $86 \%$ when exposed to pepstatin A, such as Klomklao, Kishimura, Yabe, \& Benjakul (2007) reported total inhibition for pepstatin A in Giant grenadier Coryphaenoides pectoralis. The active band of porcine pepsin and snook were inhibited completely by the presence of pepstatin A. Similar results were reported for $B$. orbignyanus and P. maculatofasciatus (García-Carreño, Albuquerque-Cavalcanti, Navarrete del Toro, \& Zaniboni-Filho 2002; Álvarez-González, 2003). PMSF inhibited the total activity of digestive proteases by $60 \%$. This is similar to the data reported for S. aequifasciata and Labeo rohita (Chong, Natalia, Hashim, \& Ali, 2002a; Chakrabarti, Rathore, \& Kumar, 2006). Alkaline protease inhibition was 59\% with the presence of ovalbumin compared with the 5\% reported by Álvarez-González (2003) for P. maculatofasciatus. The inhibition by PMSF and ovalbumin in snook gut indicates the presence of serine proteases that act as exclusive inhibitors (García-Carreño, Albuquerque-Cavalcanti, Navarrete del Toro, \& Zaniboni-Filho, 2002; Chakrabarti, Rathore, \& Kumar, 2006). Jonás, Rágyanszki, Oláh, and Boross (1983), and García-Carreño, Albuquerque-Cavalcanti, Navarrete del Toro, and Zaniboni-Filho (2002), reported that trypsin showed more activity in carnivorous fish than omnivorous and herbivorous species, where chymotrypsin activity is greater. In this study the reduction of proteolytic activity by SBT1 was $41 \%$, similar to that reported for $S$. aurata and D. dentex (Alarcón, Díaz, Moyano, \& Abellan, 1998) where inhibition ranged from 41 to $50 \%$ of the activity. This activity was also reduced in spotted wolffish (Anarhichas minor) feed with diets with SBT1 (Savoie et al. 2011). TLCK inhibited $68 \%$ of the total activity, similar to the findings for S. formosus (Natalia, Hashim, Ali, \& Chong, 2004). TPCK, an exclusive inhibitor of chymotrypsin, reduced the activity by $17 \%$, similar to that reported by Chakrabarti, Rathore, \& Kumar (2006) in L. rohita. Inhibition results with SBT1 and TLCK, indicating the importance of trypsin and chymotrypsin in snook digestion, where trypsin activity is greater than chymotrypsin activity; this result is similar to that reported by Kumar, García-Carreño, Chakrabarti, Navarrete-Del Toro, \& Córdova-Murueta (2007) in catla Catla catla, L. rohita and grass carp Hypophthalmichthys molitrix. EDTA inhibited enzyme activity by $40.5 \%$; similar values were reported for spotted sand bass (40\%) (Álvarez-González, 2003), suggesting the presence of metalloproteases (Chong, Natalia, Hashim, \& Ali, 2002a), enzymes which are absorbed directly by enterocytes, especially essential amino acids. The 1-10 phenanthroline chelate that acts as a metalloprotease showed an inhibition of $85 \%$, a rather high value compared with those reported by Álvarez-González (2003), which fluctuated between $20-30 \%$ of enzymatic inhibition. The sensibility differences of the digestive proteases could be because the enzymatic structures could vary among species.

The three active bands showing for the snook intestine confirm the presence of proteases trypsin, chymotrypsin and metalloproteases. The molecular weight was 25 and $35 \mathrm{kDa}$ for trypsin and chymotrypsin, respectively. Rivera (2003), Rodríguez (2004), and Souza, Amaral, Albérico, Carvalho Jr, \& Bezerra (2007), reported a molecular weight of (24-26.1 kDa) for trypsin in Silk snapper (Lutjanus vivanus), white grunt (Haemulon plumierii) and spotted goatfish (Pseudupeneus maculatus). The trypsin band was affected by TLCK; SBT1 inhibited the trypsin and chymotrypsin bands, showing that trypsin inhibitors equally affect chymotrypsin activity, which was similar to the results of Alarcón, Díaz, Moyano, \& Abellan (2001), where these inhibitors inhibited the band with molecular weights of 20 and $30 \mathrm{kDa}$ in yellow snapper (Lutjanus argentiventris) and Pacific dog snapper (Lutjanus novemfasciatus). Lazo, Mendoza, Holt, Aguilera, \& Arnold (2007), reported trypsin with molecular weights of 23 and $68 \mathrm{kDa}$ and chymotrypsin with $25 \mathrm{kDa}$ in S. ocellatus. Meanwhile, Natalia, Hashim, Ali, \& Chong (2004), found trypsin and chymotrypsin with molecular weights of $32.3 \mathrm{kDa}$ and $42.1 \mathrm{kDa}$, respectively, in S. formosus. The greatest $\mathrm{Rf}$ found corresponded to the metalloproteases, which have molecular weights between 45 to $97 \mathrm{kDa}$ according to the reports for S. formosus (Natalia, Hashim, Ali, \& Chong, 2004). EDTA completely inhibited 100\% of the active bands, similar to the result reported by Alarcón, Díaz, Moyano, \& Abellan (1998) for D. dentex and $S$. aurata, revealing the dependency of these enzymes on divalent cations.

\section{Conclusion}

Considering the biochemical and physiological aspects of this study, it is demonstrated that digestion in $C$. undecimalis is constituted of a single acidic protease in the stomach that was fully inhibited, which is not resistant to $\mathrm{pH}$ and temperature changes. Instead, alkaline protease digestion is lower compared with acid protease activity and it is more stable to the variation of $\mathrm{pH}$, temperature, and it is poorly resistant to inhibitors, indicating that there is a good alkaline digestive protease capacity to hydrolyse different protein sources, specially those of animal origins. Consequently, this species can be considered a marine fish with carnivorous nutritional habits. 


\section{Acknowledgments}

Author thanks to the Consejo Nacional de Ciencia y Tecnología and the Programa Institucional de Superación Académica for the scholarship granted. To Germán Merino Araneda, and Marcia Oliva Arriagada for the advise during the Ph.D. studies and the staff at the Biochemistry Laboratory of Biochemistry DACBiol-UJAT.

\section{References}

Alarcón, F. J., Díaz, M., Moyano, F. J., \& Abellan, E. (1998) Characterization and functional properties of digestive proteases in two sparids; gilthead seabream (Sparus aurata) and common dentex (Dentex dentex). Fish Physiology and Biochemistry, 19, 257-267. http://dx.doi.org/10.1023/A:1007717708491

Al-Saraji, A. Y. J., \& Nasir, N. A. N. (2013). Effect of different dietary proteins and fats on the digestive enzymes activities in the common carp fingerlings (Cyprinus carpio L.) reared in floating cages. Mesopotamic Journal of Marine Science, 28(2), 121-130. Retrieved from http://www.iasj.net/iasj?func= fulltext\&aId $=95267$

Álvarez-González, C. A. (2003). Ontogenia enzimática y nutrición larvaria de la cabrilla arenera Paralabrax maculatofasciatus (Percoidei: Serranidae). IPN-CICIMAR, La Paz, Baja California Sur, Mexico.

Álvarez-Lajonchère, L., \& Taylor, R. G. (2003). Economies of scale for juvenile production of commom snook (Centropomus undecimalis Bloch). Aquaculture Economics and Management, 7(5/6), 273-291. http://dx.doi.org/10.1080/13657300309380345

Anson, M. L. (1938). The estimation of pepsin, trypsin, papain and cathepsin with hemoglobin. The Journal of General Physiology, 22, 79-89. http://dx.doi.org/10.1085/jgp.22.1.79

Castillo-Yañez, F. J., Pacheco-Aguilar, R., Garcia-Carreño, F. L., \& Navarrete-Del Toro, M. A. (2004) Characterization of acidic proteolytic enzymes from Monterey sardine (Sardinops sagax caerulea) viscera. Food Chemistry, 85, 343-350. http://dx.doi.org/10.1016/j.foodchem.2003.07.008

Castillo-Yáñez, F. J., Pacheco-Aguilar, R., García-Carreño, F. L., \& Navarrete-Del Toro, M. A. (2005). Isolation and characterization of trypsin from pyloric caeca of Monterey sardine Sardinops sagax caerulea. Comparative Biochemistry and Physiology, 140B, 91-98. http://dx.doi.org/10.1016/j.cbpc.2004.09.031

Chakrabarti, R., Rathore, R. M., \& Kumar, S. (2006). Study of digestive enzyme activities and partial characterization of digestive proteases in a freshwater teleost, Labeo rohita, during early ontogeny. Aquaculture Nutrition, 12, 35-43. http://dx.doi.org/10.1111/j.1365-2095.2006.00379.x

Chong, A., Natalia, Y., Hashim, R., \& Ali, A. (2002a). Characterization of protease activity in developing discus Symphysodon aequifasciatus larva. Aquaculture Research, 33, 663-672. http://dx.doi.org/10.1046/j.1365 $-2109.2002 .00702 . \mathrm{x}$

Chong, A., Hashim, R., \& Bin Ali, A. (2002b). Inhibition of protease activities in Discus Symphysodon spp. By three plant meals. Aquaculture International, 10, 433-441. http://dx.doi.org/10.1023/A:1023358216960

Costa, M. L., Radünz, N. J., Lazzari, R., Veiverberg, C. A., Sutili, F. J., \& Loro, V. L. (2011). Digestive in grass carp juveniles fed with forage and ration. Archivos de Zootecnia, 60(231), 563-570. Retrieved from http://www.uco.es/publicaciones/az/php/az.php?idioma_global=0\&revista=164\&codigo=1994.

Davis, B. J. (1964). Disc electrophoresis. II. Method and application to human serum proteins. Annals of New York Academic Science, 121, 404-427. http://dx.doi.org/10.1111/j.1749-6632.1964.tb14213.x

Das, K. M., \& Tripathi, S. D. (1991). Studies on the digestive enzymes of grass carp, Ctenopharyngodon idella (Val.). Aquaculture, 92, 21-32. http://dx.doi.org/10.1016/0044-8486(91)90005-R

Díaz-López, M., Moyano-López, F. J., Alarcón-López, F. J., García-Carreño, F. L., \& Navarrete-del Toro, M. A. (1998). Characterization of fish acid proteases by substrate-gel electroforesis. Comparative Biochemistry and Physiology, 121B, 369-377. http://dx.doi.org/10.1016/S0305-0491(98)10123-2

Essed, Z., Fernández, I., Alarcón, F. J., \& Moyano, F. J. (2002). Caracterización de la actividad proteasa digestiva de atún rojo Thunnus thynnus (Linnaeus, 1758). Boletín del Instituto Español de Oceanografía, 18(1-4), 99-107. Retrieved from http://www.revistas.ieo.es/index.php/boletin_ieo/article/viewFile/170/163

Farhoudi, A., Abedian, K. A. M., Nazari, R. M., \& Makhdoomi, Ch. (2013). Changes of digestive enzymes activity in common carp (Cyprinus carpio) during larval ontogeny. Iranian Journal of Fishery Science, 12, 320-334. Retrieved from http://www.jifro.ir/files/site1/user_files_eb12be/eng/aabedian-A-10-410-2-8ca5e7e.pdf 
Fenerci, S., \& Sener, E. (2005). In vivo and In vitro protein digestibility of rainbow trout (Oncorhynchus mykiss Walbaum, 1972) fed steam pressured or extruded feeds. Turkish Journal of Fishery and Aquatic Science, 5 , 17-22. Retrieved from http://www.trjfas.org/pdf.php?id=273

Galaviz, M. A., López, L. M., García Gasca, A., Alvarez González, C. A., ... Gisbert, E. (2015). Digestive system development and study of acid and alkaline protease digestive capacities using biochemical and molecular approaches in totoaba (Totoaba macdonaldi) larvae. Fish Physiology and Biochemistry, 41, 1117-1130. http://dx.doi.org/10.1007/s10695-015-0073-6

García-Carreño, F. L., Dimes, L. E., \& Haard, N. F. (1993). Substrate-gel electrophoresis for composition and molecular weight of proteinases or proteinaceous proteinase inhibitors. Analytical Biochemistry, 214, 65-69. http://dx.doi.org/10.1006/abio.1993.1457

García-Carreño, F. L., Albuquerque-Cavalcanti, C., Navarrete del Toro, M. A., \& Zaniboni-Filho, E. (2002). Digestive proteinases of Brycon orbignyanus (Characidae, Teleostei): Characteristics and effects of protein quality. Comparative Biochemistry and Physiology, 132B, 343-352. http://dx.doi.org/10.1016/S1096-4959 (02)00038-6

Gatlin III, D. M. (2002). Nutritional and fish health. In J. E. Halver \& R. W. Hardy (Eds.), Fish Nutrition (pp. 671-702). Academic Press San Diego, CA, USA.

Ibarra-Castro, L., \& Alvarez-Lajonchère, L. (2011). GnRHa induced multiple spawns and volition spawning of captive spotted rose snapper, Lutjanus guttatus, at Mazatlan, Mexico. Journal of the World Aquaculture Society, 42, 564-574. http://dx.doi.org/10.1111/j.1749-7345.2011.00499.x

Igbokwe, E. C., \& Downe, A. E. R. (1978). Electrophoretic and histochemical comparison of three strains of Aedes aegypti. Comparative Biochemistry and Physiology, 60B, 131-136. http://dx.doi.org/10.1016/03050491(78)90117-7

Izvekova, G. I., Solovyev, M. M., Kashinskaya, E. N., \& Izvekov, E. I. (2013). Variations in the activity of digestive enzymes along the intestine of the burbot Lota lota expressed by different methods. Fish Physiology and Biochemistry, 39, 1181-1193. http://dx.doi.org/10.1007/s10695-013-9773-y

Jiménez-Martínez, L. D., Alvarez-González, C. A., Tovar-Ramírez, D., Gaxiola, G., Sanchez-Zamora, A., Moyano, F. J., ... Palomino-Albarrán, I. G. (2012). Digestive enzyme activities during early ontogeny in Common snook (Centropomus undecimalis). Fish Physiology and Biochemistry, 38, 441-454. http://dx.doi.org/10.1007/s10695-011-9525-9

Jónás, E., Rágyanszki, M., Oláh, J., \& Boross, L. (1983). Proteolytic digestive enzymes of carnivorous (Silurus glanis L.), herbivorous (Hipophthalmichthys molitrix Val.) and omnivorous (Cyprinus carpio L.) fishes. Aquaculture, 30, 145-154. http://dx.doi.org/10.1016/0044-8486(83)90158-8

Klahan, R., Areechon, N., Yoonpundh, R., \& Engkagul, A. (2009). Characterization and activity of digestive enzymes in different sizes of Nile tilapia (Oreochromis niloticus L.) Kasetsart Journal (Natural Science), 43, 143-153. Retrieved from http://kasetsartjournal.ku.ac.th/kuj_files/2009/A0902161440454040.pdf

Klomklao, S., Kishimura, H., Yabe, M., \& Benjakul, S. (2007). Purification and characterization of two pepsins from the stomach of pectoral rattail (Coryphaenoides pectoralis). Comparative Biochemistry and Physiology, 147B, 682-689. http://dx.doi.org/10.1016/j.cbpb.2007.04.008

Korostelev, S. G., Nevalenny, A. N., \& Levchenko, O. E. (2005). Characterization of digestive enzymes in the intestine of the Pacific halibut Hippoglossus stenolepis Schmidt, 1904 and the starry flounder Platichthys stellatus (Pallas, 1788). Russian Journal of Marine Biology, 31(3), 196-199. http://dx.doi.org/10.1007/ s11179-005-0068-8

Kumar, S., García-Carreño, F. L., Chakrabarti, R., Navarrete-del Toro, M. A., \& Córdova-Murueta, J. H. (2007). Digestive proteases of three carps Catla catla, Labeo rohita and Hypophthalmichthys molitrix: partial characterization and protein hydrolysis efficiency. Aquaculture Nutrtition, 13, 381-388. http://dx.doi.org/ 10.1111/j.1365-2095.2007.00488.x.

Kunitz, M. (1947). Crystalline soybean trypsin inhibitor II. General properties. Journal of General Physiology, 30, 291-310. http://dx.doi.org/10.1085/jgp.30.4.291

Kuz'mina, V. V. (2008). Classical and modern concepts in fish digestion. In J. E. P. Cyrino, D. P. Bureau, \& B. G. Kapoor (Eds.), Feeding and digestive functions of fishes (pp 85-154). Science Publishers, Enfield. 
Laemmli, U. K. (1970). Cleavage of structural proteins during the assembly of the head of bacteriophage T4. Nature, 227, 680-685. http://dx.doi.org/10.1038/227680a0

Lazo, J. P., Mendoza, R., Holt, G. J., Aguilera, C., \& Arnold, C. R. (2007). Characterization of digestive enzymes during larval development of red drum (Sciaenops ocellatus). Aquaculture, 265, 194-205. http://dx.doi.org/10.1016/j.aquaculture.2007.01.043

Lazzari, R., João Radünz, N. J., Araújo, P. F., Lucia, L. V., Pretto, A., \& Rosa, G. C. (2010). Protein sources and digestive enzyme activities in jundiá (Rhamdia quelen). Science Agriculure (Piracicaba, Brazil), 67(3), 259-266. http://dx.doi.org/10.1590/S0103-90162010000300002

Ma, H., Cahu, C., Zambonino, J., Yu, H., Duan, Q., ... Mai. K. (2005). Activities of selected digestive enzymes during larval development of large yellow croaker (Pseudosciaena crocea). Aquaculture, 245(1-4), 239-248. http://dx.doi.org/10.1016/j.aquaculture.2004.11.032

Murashita, K., Fukada, H., Takahashi, N., Hosomi, N., Matsunari, H., ... Yamamoto, T. (2015). Effect of feed ingredients on digestive enzyme secretion in fish. Bulletin Fishery Research Agenda, 40, 69-74. Retrieved from https://www.fra.affrc.go.jp/bulletin/bull/bull40/40-02-08.pdf

Natalia, Y., Hashim, R., Ali, A., \& Chong, A. (2004). Characterization of digestive enzymes in a carnivorous ornamental fish, the Asian bony tongue Scleropages formosus (Osteoglossidae). Aquaculture, 233, 305-320. http://dx.doi.org/10.1016/j.aquaculture.2003.08.012

Rivera, S. M. (2003). Purification and characterization of trypsin from intestinal and pyloric caecal tissues of the silk snapper, Lutjanus vivanus (Cuvier, 1828) (Unpublished master's thesis). University of Puerto Rico.

Rodríguez, M. A. R. (2004). Purification and kinetic characterization of trypsin from the intestine and pyloric caeca of the white grunt, Haemulon plumierii, (Lacepède, 1801) (Unpublished master's thesis). University of Puerto Rico.

Sáenz, R. M., Alarcón, F. J., Martínez, M. I., Ruiz, F., Díaz, M., \& Moyano, F. J. (2005). Caracterización de las proteasas digestivas del lenguado senegalés Solea senegalensis Kaup, 1858. Boletín del Instituto Español de Oceanografía, 21(1-4), 95-104. Retrieved from http://bashanfoundation.org/manolo/manololenguado.pdf

Sankar, H. H. S., Varadarajan, R., Bhanu, S. V., Joy, S., \& Philip, B. (2014). Functional zonation of different digestive enzymes in Etroplus suratensis and Oreochromis mossambicus. International Journal of Science Research Publicarions, 4(5), 1-10. Retrieved from http://www.ijsrp.org/research-paper-0514/ijsrp-p29105.pdf

Savoie, A., Le François, N. R., Lamarre, S. G., Blier, P. U., Beaulieu, L., \& Cahu, C. (2011). Dietary protein hydrolysate and trypsin inhibitor effects on digestive capacities and performances during early-stages of spotted wolffish: Suggested mechanisms. Comparative Biochemistry and Physiology, 158A(4), 525-530. http://dx.doi.org/10.1016/j.cbpa.2010.12.017

Souza, A. A., Amaral, I. P. G., Albérico, R. E. S., Carvalho Jr, L. B., \& Bezerra, R. S. (2007). Trypsin-like enzyme from intestine and pyloric caeca of spotted goatfish (Pseudupeneus maculatus). Food Chemistry, 100, 1429-1434. http://dx.doi.org/10.1016/j.foodchem.2005.12.016

Stauffer, C. (1989). Enzyme Assays for Food Scientists. Van Nostand Reinhold/AVI, New York, USA.

Tengjaroenkul, B., Smith, B. J., Caceci, T., \& Smith, S. A. (2000). Distribution of intestinal enzyme activities along the intestinal tract of cultured Nile tilapia, Oreochromis niloticus L. Aquaculture, 182, 317-327. http://dx.doi.org/10.1016/S0044-8486(99)00270-7

Thongprajukaew, K., Kovitvadhi, U., Engkagul, A., \& Rungruangsak-Torrissen, K. (2010) Characterization and expression levels of protease enzymes at different developmental stages of Siamese fighting fish (Betta splendens Regan, 1910). Kasetsart Journal (Natural Science), 44, 411-423. Retrieved from http://kasetsartjournal.ku.ac.th/kuj_files/2010/A1006241011134591.pdf

Tucker Jr, W. (2003). Snook culture. World Aquaculture. December 42-46.

Tufan, E. O., Suzer, C., Taşbozan, O., \& Tabakoğlu, S. (2008). The effects of rate-restricted feeding regimes in cycles on digestive enzymes of gilthead sea-bream, Sparus aurata. Turkish Journal of Fishery and Aquatic Science, 8, 49-54. Retrieved from http://www.trjfas.org/uploads/pdf_588.pdf

Walter, H. E. (1984). Proteinases: methods with hemoglobin, casein and azocoll as substrates. In H. J. Bergmeyern (Ed.), Methods of Enzymatic Analysis (pp. 270-277). Verlag Chemie Weinham. 
Wang, H., Wang, Y., Wang, Q., Xue, C., \& Sun, M. (2006). Purification and characterization of stomach protease from the turbot (Scophthalmus maximus L.). Fish Physiology and Biochemistry, 32, 179-188. http://dx.doi.org/10.1007/s10695-006-0010-9

Xiong, D. M., Xie, C. X., Zhang, H. J., \& Liu, H. P. (2011). Digestive enzymes along digestive tract of a carnivorous fish Glyptosternum maculatum (Sisoridae, Siluriformes). Journal of Animal Physiology and Animal Nutrition, 95, 56-64. http://dx.doi.org/10.1111/j.1439-0396.2009.00984.x

Zhao, L., Budge, S.M., Ghaly, A.E., Brooks, M. S., \& Dave, D. (2011). Extraction, purification and characterization of fish pepsin: A critical review. Journal of Food Processing Technology, 2, 1-14. http://dx.doi.org/10.4172/2157-7110.1000126

\section{Copyrights}

Copyright for this article is retained by the author(s), with first publication rights granted to the journal.

This is an open-access article distributed under the terms and conditions of the Creative Commons Attribution license (http://creativecommons.org/licenses/by/4.0/). 